Journal of Southeast Asian

\title{
Trauma and Second Language Learning among Laotian Refugees
}

Daryl Gordon

Adelphi University, dgordon@adelphi.edu

\section{Recommended Citation}

Gordon, Daryl (2011) "Trauma and Second Language Learning among Laotian Refugees," Journal of Southeast Asian American Education and Advancement. Vol. 6 : Iss. 1, Article 13.

DOI: $10.7771 / 2153-8999.1029$

Available at: https://docs.lib.purdue.edu/jsaaea/vol6/iss1/13

This document has been made available through Purdue e-Pubs, a service of the Purdue University Libraries. Please contact epubs@purdue.edu for additional information.

This is an Open Access journal. This means that it uses a funding model that does not charge readers or their institutions for access. Readers may freely read, download, copy, distribute, print, search, or link to the full texts of articles. This journal is covered under the CC BY-NC-ND license. 


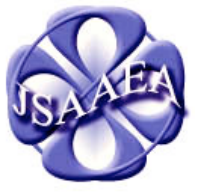

Volume 6 (2011)
Journal of Southeast Asian American Education \& Advancement

WWw.JSAAEA.org
A peer-reviewed scholarly journal published by the National Association for the Education \& Advancement of Cambodian, Laotian, and Vietnamese Americans (NAFEA)

\title{
Trauma and Second Language Learning Among Laotian Refugees
}

\author{
Daryl M. Gordon \\ Adelphi University
}

\begin{abstract}
Unprecedented numbers of adult refugee learners are entering ESL classes, many of whom escaped war-torn countries and endured long stays in refugee camps. Research in public health and psychology has documented high levels of depression, anxiety, and posttraumatic stress disorder in refugee populations. Drawing on ethnographic research with Laotian refugee women who experienced pre-settlement trauma during the Vietnam War and interviews with bilingual mental health professionals, this article examines current second language acquisition theories to consider how they elucidate the effect of trauma on second language learning. The article offers cross-cultural perspectives about the impact of trauma on learning and recommendations for working with adult refugee learners who have experienced trauma. Findings have implications for ESL instructors and second language researchers concerned with the impact of presettlement experiences on second language acquisition and implications for classroom instruction.
\end{abstract}

KEY WORDS: Laotian American, refugee, post-traumatic stress disorder, second language acquisition, ESL learner

As an ESL teacher and researcher of Laotian refugees, many students told me of the trauma they experienced as children during the Vietnam War. Large numbers of adult ESL learners enter the U.S. each year as refugees, many of whom escaped violent conditions in their native countries. Refugees who have escaped armed conflict may have experienced multiple traumatic events in their native countries or in prolonged stays in refugee camps awaiting final resettlement. Nicholl and Thompson (2004) report that while the prevalence of post-traumatic stress symptoms ranges widely among different populations, studies indicate that between $30 \%$ and $86 \%$ of refugees experience trauma-related symptoms.

The concept of trauma in psychology refers to responses to dangerous and shocking events which shatter one's sense of security and overwhelm normal resilience to adversity. Traumatic events "generally involve threats to life or bodily integrity, or a close personal

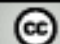

SOBRERIGHISRESERVED Readers are free to copy, display, and distribute this article, as long as the work is attributed to the author(s) and the Journal of Southeast Asian American Education \& Advancement, it is distributed for noncommercial purposes only, and no alteration or transformation is made in the work. More details of this Creative Commons license are available at http://creativecommons.org/licenses/by-nc-nd/3.0/. All other uses must be approved by the author(s) or JSAAEA.

Journal of Southeast Asian American Education \& Advancement, Vol. 6 (2011) 
encounter with violence and death. They confront human beings with the extremities of helplessness and terror and evoke the responses of catastrophe" (Herman, 1997, p. 33). Symptoms of trauma range widely among individuals, with posttraumatic stress disorder (PTSD) being the most severe.

ESL teachers play a key role for refugee learners who have survived trauma as one of the first links to their new country and a main source of cultural information. When ESL students enter the classroom, they are coping with multiple stressors and may be at different stages in recovery from trauma. Instructors should not anticipate that survivors of trauma will have resolved their traumatic memories before entering the classroom (Horsman, 2000). ESL learners in particular, who need survival ESL to manage the communicative needs of daily life, often enter the classroom while still recovering from trauma. The Canadian Centre for Victims of Torture (CCVT, 2004) posits that the stability of the classroom can help trauma survivors reconnect with ordinary life and begin to acculturate to the new country. The Harvard Program in Refugee Trauma (n.d.) states that developing second language skills reduces social isolation and increases independence, while obtaining citizenship increases the "survivor's sense of security and well-being" (p. 1).

This article draws on ethnographic research with Laotian refugee women who experienced pre-settlement traumas during the Vietnam War and interviews with bilingual/bicultural mental health providers who worked with Southeast Asian refugees. This article examines current second language acquisition theories to consider how they elucidate the effects of trauma on second language learning and offers cross-cultural perspectives about the impact of trauma on learning. Findings have implications for ESL instructors and second language researchers concerned with the impact of pre-settlement experiences on second language acquisition and implications for classroom instruction.

\section{Trauma and the Second Language Learner}

Since 1975, more than 2 million refugees have settled permanently in the U.S. In the 1980s, the majority of refugees entered from Latin America, Southeast Asia, and the Caribbean. In the 1990s, refugees entered the U.S. from war-torn countries such as Afghanistan, Bosnia, Iraq, Burundi, Sudan and Somalia (McBrien, 2005). Psychological studies have found alarmingly high rates of depression, anxiety, substance abuse, and posttraumatic stress disorder (PTSD) among refugee populations (Jaranson et al., 2004; Mollica, Wyshak, \& Lavelle 1987; Westermeyer \& Her, 2007).

Stevens' (2001) study of Cambodians in Australia revealed that 91\% of the participants experienced symptoms related to PTSD and depression. Many of the study participants experienced symptoms which directly affected learning and cognitive function, including headaches (69\%), poor concentration (58\%), and loss of memory (57\%). A study of Vietnam veterans with combat-related PTSD indicated that they scored significantly lower on tests for short-term recall and long-term memory storage than did subjects without PTSD (Bremner et al., 1993).

Instructor and anecdotal reports have explored the impact of trauma on learning. Horsman's (2000) groundbreaking study explores the impact of violence on adult learners. Although it reveals the extent of domestic and sexual violence on women's learning, Horsman's work focuses on native speakers of English and does not expressly examine language acquisition. 
A few studies have specifically examined the impact of trauma on adult ESL learners (Isserlis, 2000; Kerka, 2002; Stone, 1995). Ying (2001) provides a case study of a Vietnamese man who suffered from severe headaches, frequent nightmares, and anxiety. He was referred for treatment from his physician in part because he had complained of poor concentration, which made it difficult to attend in his ESL class. In treatment with Ying, Mr. C. revealed that he had been imprisoned in a "reeducation camp" for thirteen years where he had been tortured.

Santoro (1997) documents problems of low motivation, high rates of anxiety, and reluctance to participate verbally among adult refugee learners who are trauma survivors. McDonald (2000) documented that trauma-related symptoms including inability to concentrate, dissociation, and memory problems affected cognitive function and impaired learning among adult refugees in Canada.

The most comprehensive study of trauma's impact on language acquisition is Söndergaard and Theorell's (2004) nine-month longitudinal study of Iraqi refugees in Sweden. Researchers found that refugees who reported more severe PTSD symptoms learned a second language at a significantly slower rate. In fact, the speed of language acquisition was more highly correlated with the severity of PTSD $(p=.001)$ than the number of hours of language classes received $(p=.178)$ or previous education level in home country $(p=.116)$. The authors note that because previous studies explored the cognitive impact of trauma among nativespeaking subjects who had experienced combat trauma rather than refugee groups, trauma's impact on language acquisition may have been greatly underestimated. The authors conclude that early detection and treatment of PTSD in refugee populations could play a crucial role in minimizing post-migration stress and facilitating integration of refugees into the host society (Söndergaard and Theorell, 2004).

\section{Theoretical Perspectives: The Impact of Trauma on Second Language Acquisition}

Despite the importance of second language acquisition for refugee integration and the key role of ESL teachers in early refugee acculturation, the field of second language acquisition has neither developed a theory about the impact of trauma on second language learning nor offered recommendations for working with trauma survivors in the classroom. However, second language acquisition demonstrates that cognitive processing, attention, and memory, factors that are affected by traumatic experiences, are key to second language acquisition.

Schmidt's noticing hypothesis (1990, 1993; Schmidt \& Frota, 1986) states that only what learners notice in input can be used as intake for second language acquisition. Ellis (2006) notes that explicit learning and consciousness, including noticing negative evidence and attending to language form in many contexts, are central to second language acquisition.

Research in cognitive psychology reveals that traumatic experiences alter neural pathways in the brain and may impact learning throughout the lifespan. The human brain is designed to sense, process, and store dangerous events. All areas of the brain and body are involved in this "fight or flight response," enabling individuals to respond quickly to threatening situations. Because so many areas of the brain are involved in this response, traumatic events impact the brain in a pervasive and profound fashion (Perry, 1999).

In individuals with PTSD, this life-saving response interferes with the ability to process information. These individuals may be triggered by a sound (fireworks) or event (a crowded room) which initiates the fear response. In turn, the brain responds to the trigger with a pervasive terror response, as if it were occurring for the first time. This flashback, or retriggering of the 
terror response, puts the brain in a high alert mode. However, in order to process, store, retrieve, and respond to new learning, the brain must be in a calm and attentive state. When a trauma survivor is in a state of fear, the brain, especially areas in the cerebral cortex that processes language learning, is involved in the fight or flight response and not available to process new information (Perry, 2006).

Krashen's $(1982,1985)$ affective filter hypothesis offers promising connections for research with traumatized language learners. Krashen posited that affective factors including anxiety and self-confidence play an important role in second language acquisition. Low selfesteem and debilitating anxiety combine to raise the learners' affective filter, creating a mental barrier that prevents comprehensible input from reaching the language acquisition device.

While Krashen's theory has been criticized because of the lack of supporting empirical research, recent neurological research demonstrates that students' level of anxiety influences information transmission and storage. Neuroimaging and neurotransmitter studies demonstrate that under stress, information is blocked from entering the brain's areas of higher cognitive memory consolidation and storage. In other words, "when stress activates the brain's affective filters, information flow to the higher cognitive networks is limited and the learning process grinds to a halt" (Willis, 2007, p. 1). Because trauma survivors often deal with anxiety and eroded self-confidence, research on the neuroscience of learning and the role of the affective filter are particularly important for traumatized learners. While theories such as the affective filter and cognitive processing allude to the respective roles of anxiety and attention in language learning, these concepts have not been explored in the context of traumatized learners.

\section{Historical Background of Laotian Refugees}

Laotian refugees settled in the U.S. as part of a massive influx of nearly one million Southeast Asians from Vietnam, Cambodia, and Laos, who sought refuge after the Vietnam War ended in 1975. Because of its border with Vietnam, Laos became the target of a "secret war" conducted by the U.S. to bomb supply routes to Vietnam. Between 1964 and 1973, the country was bombed continually, destroying village life as Laotian people sought refuge in caves or in the jungle. When the communist government took power in Laos in 1975, refugees fled for neighboring Thailand (Hein, 1995; Stuart-Fox, 1997).

The escape from Laos was fraught with danger. Refugees were at the mercy of Lao soldiers who would shoot escaping refugees; pirates routinely stopped refugee crafts to rob or rape passengers. Laotians endured long stays in refugee camps before final resettlement in their host country. Most camps were detention centers, holding refugees inside barbed wire compounds with minimal provisions of food and shelter. The principal participants in this study spent between two and five years in refugee camps. Many Lao refugees recounted incidents of violence, including beatings and rapes from gangs of refugees within the camp and from Thai military who oversaw the camps. Health problems were common in overcrowded conditions, where there was little access to adequate health care, food, or water (Hein, 1995). All of the women interviewed lost family members in their resettlement journey; family members were killed during the war, in the escape from Laos, or due to illnesses in the refugee camps.

Upon entry into the U.S., refugees were often met with mistrust and hostility by a host country, healing its wounds from a controversial war that had killed many American men.

The Laotian experience of trauma is complicated by the fact that the American government played a dual role in the trauma they experienced, as both provider of refuge from 
the war and the party responsible for the widespread bombing of Lao villages. Branfman (1972), who worked with Lao refugees during the Vietnam War, commented that, "Most of the refugees have fled one form or another of American firepower. As a result, they tend to distrust, fear or hate Americans" (p. 12). This perception of the U.S. and its role in Laotian learners' trauma is part of the complex social history of these learners. While a detailed exploration of Laotian migration history and national belonging is beyond the scope of this article, I have explored this topic further in Gordon (2010).

\section{Methodology}

My involvement in the Laotian refugee community began in 1994 when I volunteered as a tutor in an ESL class for Southeast Asian adults. In 1997, I initiated a three-year ethnographic research project within the Laotian refugee community. Initial data collection took place between 1997 and 2000 in an urban, working class Lao-American community and in Laos as part of a research project focusing on women's second language socialization (Gordon 2003, 2004, 2009). Data presented in this article were collected primarily through practitioner research in a year-long ESL class for Laotian adults in Philadelphia. This article offers vignettes of three of these students, whose life and learning seemed most affected by traumatic pre-settlement events. The vignettes are intended to provide an ethnographic account of the multiple factors, including pre-settlement trauma, which affected the learning of these students. I conducted at least two formal interviews with each of these principal participants, focusing on their pre-settlement experiences and their process of second language learning in the U.S. I also conducted intensive participant observation with the principal participants, spending time with them in their homes, at religious observances at the Lao Temple, and at their workplaces.

Pha, Ouma, and Viseth, the three female participants whose vignettes are featured in this article, lived in a low-income Philadelphia neighborhood whose residents were mainly AfricanAmerican, Cambodian, and Laotian. All were ethnic Lao and had entered the U.S. as adults after 1980, after spending between two and five years in refugee camps in Thailand and the Philippines. At the time of the study, the principal participants ranged from early thirties to early forties; all were married with children. The participants had received limited formal education in Laos; two of the participants struggled with native language literacy, which hindered acquisition of English literacy. In the U.S., they worked in non-union factory jobs, where they had little contact with native speakers of English. Their stated goals for learning English were to become U.S. citizens and to be able to use English in situations such as interactions with the doctor and children's school.

In 2009, in preparation for this article, I conducted telephone interviews with four bilingual mental health workers who are native speakers of Lao, Khmer, and Vietnamese. Two individuals founded a Southeast Asian Mental Health Program in 1984 in order to serve the needs of large populations of refugees entering the area, and both have worked as social service coordinators in the community since the program's inception. The third individual is a social worker who works with Cambodian clients in that program. The fourth individual is a therapist with Intercultural Family Services who works primarily with Southeast Asian clients who have survived traumatic events. 


\section{Vignettes of Principal Participants}

Students frequently told me of dangerous escapes from Laos or experiences during the war in the context of individual interviews or private conversations. As more students shared these experiences, learners began to bring up the topic in class discussions and some chose to write journal entries about experiences during the war. My participant observation in the LaoAmerican community facilitated students' familiarity and trust, which may have made them more comfortable in sharing these experiences. While learners often related experiences during the war, I suspect that many stories of personal traumas were not disclosed. In particular, no women shared stories of sexual violence, which is well-documented in the literature on Southeast Asian refugees (Hein, 1995; Sylapheth, personal communication, July 2009). While not surprising, given the stigma surrounding sexual violence in this community, teachers should be aware that learners may disclose only some of the events they experienced (See Horsman, 2000, for a discussion of learner disclosure in writing activities). Below are vignettes of the migration experiences of three Laotian women who were trauma survivors and the challenges they experienced in the ESL class.

\section{Pha}

Pha was six years old when she witnessed the bombing of her aunt's house in which her relatives were killed. To avoid the relentless bombing, Pha's family sought safety in the capital city, walking nearly two hundred miles. Soon after she married at 15, Pha's husband was imprisoned in a reeducation camp for 9 years. In 1984, when her husband escaped, they fled Laos with their four children. Because she feared that the family would be killed in the escape, Pha made the excruciating decision to leave her oldest son with her parents in Laos. Pha's family was in a refugee camp for two years, during which all her children contracted tuberculosis and one child nearly died of a parasitic infection. Describing an ESL class she took in the refugee camp, Pha told me that it was difficult to concentrate in those circumstances. She said, "Why study what? For what? Your kid crying next to you, you hear it. It's bother your mind, cannot study nothing" (Interview, October 1998).

While Pha enjoyed ESL class in the U.S., studying continued to be difficult for her. She often complained of headaches and fatigue, which sometimes prevented her from attending class. She took multiple medications - both natural remedies and those prescribed by doctors. She felt that bad memories from the war contributed to the headaches. She also worried a great deal about her sons, one of whom was in jail on an aggravated assault charge connected to a drug sale. Pha's family had multiple problems with housing and faced eviction at one point during the class. These problems sometimes distracted Pha, so her level of participation and attention varied greatly in class sessions. When she was able to focus and engage in class activities, she was an inquisitive and independent student. At other times, she seemed consumed by worry and pain.

\section{Ouma}

Ouma's family lived in Southern Laos. Her family moved multiple times in an attempt to evade the bombing raids. Although she is not certain of her exact age when her family first left their village, she remembers being so young that she could only carry a small basket of rice as her family fled. Her family was displaced by the bombing for most of her childhood and 
adolescence, and did not return to their original home until Ouma was 18. Describing this time in which they hid in the jungle to avoid the planes that continually bombed her village, Ouma said:

Hide from the planes, we scare they shoot us. And then the planes they go down very low and then all day all night. We go out in the jungle. ... We go the place it's safe.... And then at nighttime, we still live in the jungle. It's very big, jungle tree and mosquito bite. We want to cook, but we scared the smoke_-plane could see and then shoot. ... A lot of people got killed (Interview, January 1999).

Ouma escaped from Laos with her husband in 1981, using inner tubes to cross the Mekong River. After five years in a refugee camp, Ouma and her family arrived in the U.S. in 1986. Upon entering my ESL class, her goals were to pass the citizenship exam, to understand and complete forms more easily, and to enter a cosmetology program. However, while a good student with intermediate level proficiency in listening and speaking, Ouma missed many classes. I began to wonder whether she was motivated to continue the class. She explained that she had been unable to find stable work and her employer called without prior notice when they needed workers. We continued our work through private tutoring lessons which were adaptable to her shifting work schedule. However, Ouma had to stop her lessons when she fled the city because of an abusive relationship with her husband. Her plans for education have been put on hold indefinitely.

\section{Viseth}

Viseth's family lived in Southern Laos. At the age of twelve, she was captured by the North Vietnamese Army. Viseth was forced at gunpoint to walk through the jungle for days to the Vietnamese border with guns and bullet rounds strapped to her chest. Two of Viseth's brothers were killed in the war. At 21, Viseth escaped from Laos, swimming across the Mekong with a group of four others. She described a treacherous trip in which two of her friends drowned. She arrived in Thailand with no clothes and no money because they had been swept away by the strong river current. After years in the refugee camp, Viseth entered the U.S. in 1982, finding an apartment in a poor inner city community. During her first year in the U.S., she was robbed at knife-point when she was at home alone with her three month old baby. This was a profoundly difficult experience for Viseth, as it reactivated previous traumatic events and she did not speak enough English to communicate with the robber or with police.

Viseth enjoyed the social aspect of the ESL class and often entertained fellow students with stories told in English and Lao about events at her job and with her children. However, ESL class was often difficult for her. Despite having been in the U.S. for many years, she had never taken an ESL class before, as she worked long hours in a factory and had young children. She had little native language literacy in Lao, so acquiring English literacy was frustrating. She often complained of difficulty remembering English words and phrases and began to assert that she was "too old" to learn English. Complicating matters, she often came to class exhausted, so her attention was impaired.

These learners experienced many obstacles in their path to learning English. Evidence of trauma including memory and attention problems, fatigue, depression, and somatic symptoms as well as current stress - remained significant factors in their language learning difficulties. However, during the course, I was unable to locate second language acquisition studies that 
helped me to understand how their traumatic experiences contributed to their language learning difficulties. The following section discusses findings from Southeast Asian Mental Health providers, in order to provide a context for student experiences.

\section{Findings from Mental Health Providers}

Interviews with bilingual mental health professionals who work closely with Southeast Asian trauma survivors offered insight into the cultural perspectives that influence how Southeast Asian clients conceptualize traumatic events. While the basic emotions accompanying traumatic events are universally felt, research with refugee trauma survivors from diverse cultures indicates that culture influences how suffering is conceptualized, how strong emotions are expressed, and how individuals cope with grief (Wilson and Drožđek, 2004).

\section{Mental Health Stigma}

Each of the mental health professionals interviewed stated that despite treating many clients with depression, anxiety, and PTSD, mental health problems were highly stigmatized in Southeast Asian culture. Clients worried that others in the close-knit refugee community would learn of their mental health problems, which would reflect badly on the family. In Southeast Asian culture, mental health problems are regarded as hereditary, so admission of a problem is damaging to the family reputation (Lu, personal communication, July 2009). Refugees may also fear that reports of mental illness will spread to government agencies, resulting in deportation or discontinuation of government benefits (Gong-Guy, Cravens, \& Patterson, 1991).

Contributing to this stigma is the belief that violent or traumatic events are the result of karma, the Buddhist belief that one's actions shape past, present, and future experiences. In this world view, particularly strong among Cambodian and Laotian followers of Theravada Buddhism, traumatic events are the result of misdeeds one committed in a former life or which one's ancestors committed (Math, personal communication, July 2009; Ying, 2001).

\section{Somatic Symptoms}

Southeast Asian survivors of trauma often present with somatic symptoms, rather than discussing depression or grief, as the culture views body and mind as more interconnected than in Western culture and does not make a clear distinction between physical and emotional pain. Bunrath Math stated that clients often visit him after having sought help for physical problems such as headaches, insomnia, and chest pain for many years. He said that clients often come with multiple prescriptions for physical problems and are frustrated that they have not cured the symptoms. Ying (2001) similarly notes that Southeast Asian trauma survivors who seek treatment in her community mental health clinic conceive of their problem as "primarily somatic" (p. 71). Gong-Guy et al. (1991) notes that the tendency to focus on physical complaints may be related to traditional backgrounds that discourage the direct expression of feelings or to more holistic views of body and mind.

\section{Learner Communities}

Traumas such as wars and natural disasters impact the entire community. Despite commonly held beliefs that communities unite in difficulty, catastrophic events "force open whatever fault 
lines once ran silently through the structure of the larger community, dividing it into divisive fragments" (Erikson, 1995, p. 189). This is an important consideration for ESL teachers who may assume that learners who speak the same language or are from the same area share a common experience and similar beliefs. However, this is often not the case, especially for learners in refugee communities who have fled political conflicts.

Strong divisions existed in the Laotian refugee community between community members who advocated establishing relations with the Laotian Embassy and those who refused to recognize the current communist government. Socioeconomic differences, which became heightened during the war, were important distinctions within the community. During a class activity in which students created timelines of their lives, a long discussion ensued about the ways people escaped from Laos. Some were considered fortunate enough to hire a boat, others escaped on inner tubes, and still others crossed the Mekong without any device. In a later class, as we discussed a news story about a Southeast Asian refugee, one learner reported that access to water was a major problem in the refugee camp and that fights sometimes broke out as refugees waited in long lines for water. After class, another student pointedly informed me that the woman who told the story never had that experience, because she was among the privileged who were able to pay someone to wait in line and to bring her water. She then related her personal struggles in the refugee camp.

\section{Revealing Traumatic Events}

Cultures differ widely about whether disclosure of traumatic events is considered an important step in healing from trauma. Horsman (2000) writes eloquently of the empowerment that many women survivors of abuse experience from disclosing traumatic events. This concept of breaking the silence has been an important contribution of western feminist research and activism on domestic and sexual violence. However, the importance of relating the traumatic event as part of the healing process may not be shared by other cultures (von Peter, 2009). Cultural beliefs influence "what is seen as private and public pain ... what should be shared with others and what must remain a secret" (Drožđek, 2007, p. 8).

Lu recounted the story of a Southeast Asian woman who had been raped in the refugee camp. The woman was in great psychological and physical distress and experiencing flashbacks. A close friend, who had been raped in the same camp, urged her not to mention the rape and to forget about the incident. While the friend's reaction may seem unsympathetic from a Western point of view, she was concerned about the impact of community gossip about the rape, which would prevent the woman from finding a husband (Lu, personal communication, July 2009). Tankink and Richters (2007) discuss silence as a coping strategy among women who were raped during war in Sudan. Because rape is perceived as shameful to the woman, maintaining silence is essential to prevent gossip within the refugee community.

The themes above demonstrate how Southeast Asian refugees may experience, understand, and respond to traumatic events differently from Americans of other cultural backgrounds. Becoming familiar with students' cultural backgrounds and the circumstances that forced them to leave their countries can help the ESL teacher work more effectively with trauma survivors. 


\section{Interaction of Past Trauma and Current Stressors}

Coping with traumatic memories is one of many stressors experienced by refugees. Refugees are adapting to a new culture and language while experiencing stress related to the practical difficulties of migrating to a new country, including locating housing, employment, and education, without access to traditional social support (Adkins, Sample, \& Birman, 1999). Ongoing stress in the host country plays a major role in a refugee's recovery from trauma (Drožđek, 2007; Oorth, Doorschodt, Verburgt, \& Drožđek, 2004).

Each of the mental health workers pointed out past traumas and current stressors as mutually reinforcing. Difficulties locating affordable housing, supporting family members on low-wage jobs, and communication difficulties were significant problems in the lives of the refugees with whom they worked. Also, intergenerational acculturation patterns within the family complicate trauma recovery, as the children of refugees may not understand or appreciate the abuses that occurred during the war (Sylapheth, personal communication, July 2009).

In understanding the experiences of refugee ESL learners, it is crucial to appreciate the complexity of stressors that may affect second language learning. Researchers acknowledge the convergence of multiple factors in the health of refugees. Nou (2006) highlights the concurrence of pre-migration, trauma-related stressors and ongoing stressors in the host country, writing that "most Cambodians are caught between lingering historical painful memories and the difficulties of adjusting to life in a new social environment" (p. 2). Nicholl and Thompson (2004) write of the importance of acknowledging multiple factors that affect the health of refugee populations, including prior experiences of trauma, socio-economic deprivation factors, lack of social support, and isolation arising from living in exile. Hinton, Rasmussen, Nou, Pollack, and Good (2009), in their study of family-directed anger among traumatized Cambodian refugees, point to three specific sources of post-migration stress experienced by the refugees: acculturative stress, financial stress, and stress stemming from living in neighborhoods with frequent violence and gang activity. While Laotian refugees had a very different pre-settlement experience than Cambodians, they share many of these current stressors as refugees struggling to acculturate in poor communities.

The intent of this article is not to posit that PTSD is the cause of all second language learning difficulties experienced by these students. Rather, it invites ESL teachers and second language researchers to consider the impact that pre-settlement traumatic experiences may have on language learning and the role ESL teachers may have in facilitating the second language learning of traumatized refugee learners. Toward that end, the following section details specific steps that ESL teachers may use in working with refugee learners experiencing post-traumatic stress.

\section{Implications for Teaching}

Learners who have undergone traumatic experiences may experience symptoms such as anxiety, poor concentration, and memory problems, which have direct connections to learning difficulties (Isserlis, 2000, Kerka, 2002, McDonald, 2000). Horsman (2000) suggests that rather than focusing on identifying learners who have had traumatic experiences, educators find ways to make learning safer for all students. The recommendations that follow are designed to help ESL teachers create a safe and productive learning environment. 


\section{Classroom Configuration}

Learners who have been confined or imprisoned may be sensitive to closed spaces, so keeping doors and windows open may help learners feel more comfortable. Loud noises are a trigger for some trauma survivors, so locating a quiet classroom is optimal. Because traumatized learners may have days when it is difficult to participate in class activities, creating a quiet corner in the classroom, where learners can work independently may be helpful (CCVT, 2004).

\section{Managing Concentration Difficulties}

Trauma survivors commonly experience difficulties with concentration and memory loss. The Canadian Centre for Victims of Torture writes that:

A major problem faced by survivors of torture is their inability to concentrate for long periods of time. This deficit has far-reaching implications for a survivor who is endeavoring to receive formal ESL instruction because concentration is necessary if the material presented in the class is to be absorbed. (CCVT, 2004, Concentration section, para. 1)

Because learners may struggle with concentration and memory issues, keep learning sessions short, vary group structures and activities, and include movement, music or art activities when possible (Math, personal communication, July 2009, Oorth et al., 2004). Trauma survivors may find it difficult to discuss topics, such as family relationships, if they have lost family members. Share plans for the day's agenda before starting class, so that learners can make a decision about their ability to participate (CCVT, 2004).

\section{Community Resources for Wellness}

ESL teachers can include a focus on wellness and stress management as part of their class, with mini-lessons on tai chi, meditation, or yoga. Learners may have traditional methods of relaxation which they can share with other class members. ESL teachers can develop lessons to help learners share and build their knowledge of community resources. Teachers can start this project with the simple question "Where do you go for help?" (Math, personal communication, July 2009). Learners can write a resource on an index card which could be shared on a bulletin board or in a community resource book.

\section{Learner Investment}

Many psychosocial impacts of trauma, such as dissociation, attention difficulties, missing classes, or dropping out may be interpreted as a lack of motivation (Kerka, 2002). Learners dealing with traumatic memories and adjusting to life in the U.S. may have difficulty sustaining investment in English learning and attending class regularly. However, the ESL class offers a source of structure and normalcy for learners who are often in a period of transition and upheaval. The CCVT (2004) offers strategies to encourage attendance and punctuality by asking learners to self-monitor their attendance on a classroom chart. Also, helping learners reflect on 
progress through authentic assessments at regular intervals can help learners maintain investment in language learning.

\section{Conclusion}

Increasing numbers of adult refugees enter the U.S. from war-torn countries and may have experienced pre-settlement trauma which can negatively affect their learning. Therefore, it is imperative for the ESL field to recognize and investigate trauma as a factor in language learning. This is of particular importance as the U.S. prepares to receive large numbers of Iraqi refugees. Refugees from Iraq increased more than eight-fold from 2007 to 2008 and are expected to continue rising dramatically (Office of Immigration Statistics, 2009). A study conducted among Iraqi refugees in Syria showed that all of the 754 refugees interviewed experienced at least one traumatic event, including rocket attacks, witnessing the killing of someone close to them, interrogation by militias, car bombings, and torture (United Nation High Commissioner for Refugees, 2008).

Research into how trauma impacts second language learning and cognitive processing will help the field better understand the language learning process and offer important implications for classroom instruction. The women in this study, like all trauma survivors, possess a remarkable capacity to overcome horrific events. Through acknowledging this capacity, ESL teachers can help trauma survivors draw on their indomitable strength as they adjust to their new country, so they can view their traumatic past as one aspect of their life history, rather than the defining moment.

\section{References}

Adkins, M. A., Sample, B., \& Birman, D. (1999). Mental health and the adult refugee: The role of the ESL teacher. ERIC Digest. Washington, DC: National Clearinghouse for ESL Literacy Education. (ED439625)

Branfman, F. (1972). Voices from the Plain of Jars: Life under an air war. New York: Harper \& Row.

Bremner, J. D., Scott, T. M., Delaney, R. C., Southwick, S. M., Mason, J. W., Johnson, D. R., . . . Charney, D. S. (1993). Deficits in short-term memory in posttraumatic stress disorder. American Journal of Psychiatry, 150, 1015-1019.

Canadian Centre for Victims of Torture. (2004). Torture and second language acquisition. Retrieved from http://www.ccvt.org/torture esl.html

Drožđek, B. (2007). The rebirth of contextual thinking in psychotraumatology. In B. Drožđek \& J. Wilson (Eds.), Voices of trauma: Treating survivors across cultures (pp. 191-210). New York: Springer Science.

Ellis, N. (2006). Cognitive perspectives on SLA: The associative-cognitive CREED. AILA Review, 19, 100-121.

Erikson, K. (1995). Notes on trauma and community. In C. Caruth (Ed.) Trauma: Explorations in memory. Baltimore, MD: Johns Hopkins University Press.

Gong-Guy, E., Cravens, R., \& Patterson, T. (1991). Clinical issues in mental health service delivery to refugees. American Psychologist, 46(6), 642-648. 
Gordon, D. (2003). "I'm tired. You clean and cook.": Shifting gender identities and language socialization in a Lao-American Community (Unpublished doctoral dissertation). University of Pennsylvania, Pennsylvania.

Gordon, D. (2004). "I'm tired. You clean and cook.": Shifting gender identities and second language socialization. TESOL Quarterly, 38(3), 437-457.

Gordon, D. (2009). "She's American now, I don't like that": Gendered language ideologies in a Laotian American community. Journal of Southeast Asian American Education \& Advancement, 4, 1-19. Retrieved from http://jsaaea.coehd.utsa.edu/index.php/JSAAEA/ article/view/65/62

Gordon, D. (2010). Disrupting the master narrative: Global politics, historical memory, and the implications for naturalization education. Anthropology \& Education Quarterly, 41(1), 117.

Harvard Program in Refugee Trauma. (n.d.). HPRT/ Treatment Plan. Retrieved from http://hprtcambridge.org/?page id $=69$

Hein, J. (1995). From Vietnam, Laos and Cambodia: A refugee experience in the United States. New York: Twayne Publishers.

Herman, J. L. (1997). Trauma and recovery. New York: Basic Books.

Hinton, D., Rasmussen, A., Nou, L., Pollack, M., and Good, M-J. (2009). Anger, PTSD, and the nuclear family: A study of Cambodian refugees. Social Science Medicine, 69(9), 13871394.

Horsman, J. (2000). Too scared to learn: Women, violence, and education. Mahwah, NJ: Lawrence Erlbaum.

Isserlis, J. (2000). Trauma and the adult English language learner. Washington, DC: Center for Applied Linguistics.

Jaranson, J. M., Butcher, J., Halcon, L., Johnson, D. R., Robertson, C., Savik, K., . . Westermeyer, J. (2004). Somali and Oromo refugees: Correlates of torture and trauma history. American Journal of Public Health, 94(4), 591-598.

Kerka, S. (2002). Trauma and adult learning: ERIC Digest. Columbus, OH: ERIC Clearinghouse on Adult Career and Vocational Education. (ED472601)

Krashen, S. (1982). Principles and practice in second language acquisition. New York: Pergamon Press.

Krashen, S. (1985). The Input Hypothesis: Issues and implications. New York: Longman.

McBrien, J. L. (2005). Educational needs and barriers for refugee students in the United States: A review of the literature. Review of Educational Research, 75(3), 329-364.

McDonald, S. (2000). Trauma and second language learning. The Canadian Modern Language Review, 56(4), 690-696.

Mollica, R. F., Wyshak, G., \& Lavelle, J. (1987). The psychosocial impact of war trauma and torture on Southeast Asian refugees. American Journal of Psychiatry, 144, 1567-1572.

Nicholl, C. \& Thompson, A. (2004). The psychological treatment of Post Traumatic Stress Disorder (PTSD) in adult refugees: A review of the current state of psychological therapies. Journal of Mental Health, 13(4), 351-362.

Nou, L. (2006). A qualitative examination of the psychosocial adjustment of Khmer refugees in three Massachusetts communities. Boston, MA: Institute for Asian American Studies.

Office of Immigration Statistics. (2009). Refugees and asylees: 2008, annual flow report. Washington, DC: U.S. Department of Homeland Security. 
Oorth, J., Doorschodt, L., Verburgt, J., \& Drožđek, B. (2004). Sounds of trauma: An introduction to methodology in music therapy with traumatized refugees in clinical and outpatient settings. In J. Wilson \& B. Drožđek (Eds.), Broken spirits: The treatment of traumatized asylum seekers, refugees, war and torture victims (pp. 443-480). New York: BrunnerRoutledge.

Perry, B. (1999). The memories of states: How the brain stores and retrieves traumatic experience. In J. Goodwin \& R. Attias (Eds.) Splintered reflections: Images of the body in trauma (pp. 9-38). New York: Basic Books.

Perry, B. (2006). Fear and learning: Trauma-related factors in the adult education process. New Directions for Adult and Continuing Education, 110, 21-27.

Santoro, N. (1997). Why won't they talk: The difficulties of engaging victims of trauma in classroom interaction. TESOL in Context, 7(2), 14-18.

Schmidt, R. (1990). The role of consciousness in second language learning. Applied Linguistics, 11(2), 129-158.

Schmidt, R. (1993). Awareness and second language acquisition. Annual Review of Applied Linguistics, 13, 206-226.

Schmidt, R., \& Frota, S. (1986). Developing basic conversational ability in a second language: A case study of an adult learner of Portuguese. In R. Day (Ed.), Talking to learn: Conversation in second language acquisition (pp. 237-326). Rowley, MA: Newbury House.

Söndergaard, H. P., \& Theorell, T. (2004). Language acquisition in relation to cumulative posttraumatic stress disorder symptom load over time in a sample of resettled refugees. Psychotherapy and Psychosomatics, 73(5), 320-323.

Stevens, C. A. (2001). Perspectives on the meanings of symptoms among Cambodian refugees. Journal of Psychology, 37(1), 81-98.

Stone, N. (1995). Teaching ESL to survivors of trauma. Prospect: The Journal of the Adult Migrant Education Program, 10(3), 49-58.

Stuart-Fox, M. (1997). A history of Laos. New York: Cambridge University Press.

Tankink, M., \& Richters, A. (2007). Giving voice to silence: Silence as coping strategy of refugee women from south Sudan who experienced sexual violence in the context of war. In B. Drožđek \& J. Wilson (Eds.), Voices of trauma: Treating survivors across cultures (pp. 191-210). New York: Springer Science.

United Nation High Commissioner for Refugees. (2008). Iraq: Trauma survey in Syria. Retrieved from http://www.reliefweb.int/rw/ RWB.NSF/db900SID/LSGZ-7B4H2N? OpenDocument\&rc'3\&cc'irq

von Peter, S. (2009). The concept of "mental trauma" and its transcultural application. Anthropology \& Medicine, 16(1), 13-25.

Westermeyer, J., \& Her, C. (2007). Western psychiatry and difficulty: Understanding and treating Hmong refugees. In J. Wilson \& C. S. Tang (Eds.), Cross-Cultural Assessment of Psychological Trauma and PTSD (pp. 371-394). New York: Springer Science.

Willis, J. (2007). The neuroscience of joyful learning. Educational Leadership, 64, 1-5.

Wilson, J., \& Drožđek, B. (Eds.). (2004). Broken spirits: The treatment of traumatized asylum seekers, refugees, war and torture victims. New York: Brunner-Routledge.

Ying, Y. (2001). Psychotherapy with traumatized Southeast Asian refugees. Clinical Social Work Journal, 29(1), 65-78. 


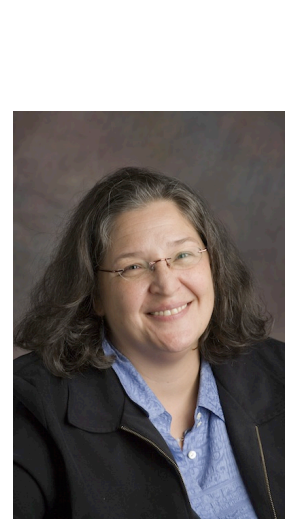

\begin{abstract}
About the Author
Daryl Gordon is an assistant professor at Adelphi University's TESOL Program, where she teaches courses in sociolinguistics, ESL methodology, and second language acquisition. She earned her doctorate in Educational Linguistics at the University of Pennsylvania. She has taught and designed curricula for ESL learners in the United States, Mexico, and the Lao PDR. Her research interests include gendered second language socialization, health literacy for ESL learners, and civic engagement for adult immigrants.
\end{abstract}




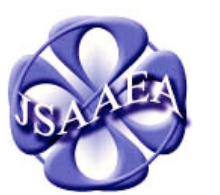

Volume 6 (2011)

\section{Journal of Southeast Asian American Education \& Advancement}

\author{
WWW.JSAAEA.org
}

\section{Editor}

Dr. Wayne E. Wright

University of Texas, San Antonio

\section{Associate Editors}

Dr. Chhany Sak-Humphry

University of Hawaii

Dr. KimOanh Nguyen-Lam

U.S. Department of Education

Book Review Editor

Dr. Vichet Chhuon

University of Minnesota

\section{Creative Works Editor \\ Bryan Thao Worra \\ Lao Assistance Center}

Special Advisor

Gregory Green

Curator, Echols Collection on Southeast Asia, Cornell University Library

\author{
Journal Manager \\ Sovicheth Boun \\ University of Texas, San Antonio
}

A peer-reviewed scholarly journal published by the

National Association for the Education \& Advancement of Cambodian, Laotian, and Vietnamese Americans (NAFEA)

Comments and questions for the editorial staff may be directed to jsaaea@lists.sis.utsa.edu

\section{Editorial Review Board}

\author{
Dr. Steve Arounsack \\ California State University, Stanislaus \\ Dr. Phala Chea \\ Lowell Public Schools \\ Dr. Loan Dao \\ Cancer Prevention Institute of California \\ Dr. Sophal Ear \\ U.S. Naval Postgraduate School \\ Dr. Nancy H. Hornberger \\ University of Pennsylvania \\ Dr. Peter Nien-Chu Kiang \\ University of Massachusetts, Boston
}

Dr. Carl L. Bankston III

Tulane University

Dr. George Chigas

University of Massachusetts, Lowell

Dr. Changming Duan

University of Missouri, Kansas City

Dr. Jeremy Hein

University of Wisconsin - Eau Claire

Dr. Samlong Inthaly

Minneapolis Public Schools

Dr. Kevin K. Kumashiro

University of Illinois, Chicago 


\author{
Dr. Jonathan H. X. Lee \\ San Francisco State University \\ Dr. Sue Needham \\ California State University, Dominguez Hills \\ Dr. Max Niedzwiecki \\ Daylight Consulting Group \\ Dr. Clara Park \\ California State University, Northridge \\ Dr. Mark Pfeifer \\ Texas A\&M University, Corpus Christi \\ Dr. Bounlieng Phommasouvanh \\ Minnesota Department of Education \\ Dr. Kalyani Rai \\ University of Wisconsin, Milwaukee \\ Dr. Fay Shin \\ California State University, Long Beach \\ Dr. Cathy J. Schlund-Vials \\ University of Connecticut, Storrs \\ Dr. Yer J. Thao \\ Portland State University \\ Dr. Myluong Tran \\ San Diego State University \\ Dr. Khatharya Um \\ University of California, Berkeley \\ Dr. Linda Trinh Vo \\ University of California, Irvine \\ Dr. Zha Blong Xiong \\ University of Minnesota
}

\author{
Dr. Stacey Lee \\ University of Wisconsin, Madison \\ Dr. Bic Ngo \\ University of Minnesota \\ Dr. Leakhena Nou \\ California State University, Long Beach \\ Dr. Isabelle Thuy Pelaud \\ San Francisco State University \\ Dr. Loan T. Phan \\ University of New Hampshire \\ Dr. Karen Quintiliani \\ California State University, Long Beach \\ Dr. Angela Reyes \\ Hunter College, The City University of New York \\ Dr. Nancy J. Smith-Hefner \\ Boston University \\ Dr. Christine Su \\ Ohio University \\ Dr. Loan Tran \\ University of California, Riverside \\ Dr. Tinou Tran \\ Alief Independent School District \\ Dr. Phitsamay Sychitkokhong Uy \\ University of Massachusetts, Lowell \\ Dr. Terrence G. Wiley \\ Center for Applied Linguistics \\ Dr. Kou Yang \\ California State University, Stanislaus
}

\section{Doctoral Student Editorial Review Board}

\author{
Keo Chea-Young \\ University of Pennsylvania \\ Ketmani Kouanchao \\ California State University, Fullerton \\ Polinda Keo \\ University at Albany \\ Ravy Lao \\ University of California, Santa Barbara \\ Thien-Huong Ninh \\ University of Southern California \\ Malaphone Phommasa \\ University of California, Santa Barbara \\ Rassamichanh Souryasack \\ University of California, Santa Barbara \\ Alisia Tran \\ University of Minnesota \\ Silvy Un \\ University of Minnesota
}

\author{
Annie BichLoan Duong \\ San Joaquin County Office of Education \\ Peter Tan Keo \\ Columbia University \\ Ha Lam \\ Arizona State University \\ Monirith Ly \\ Texas State University-San Marcos \\ Giang Pham \\ University of Minnesota \\ Vanna Som \\ Harvard University \\ Somongkol Teng \\ University of Minnesota \\ Krissyvan Truong \\ Claremount Graduate University \\ Yang Sao Xiong \\ University of California, Los Angeles
}

